Syntax Literate: Jurnal Ilmiah Indonesia p-ISSN: 2541-0849

e-ISSN: 2548-1398

Vol. 5, No. 7, Juli 2020

\title{
IMPROVING STUDENTS' ABILITY TO DESCRIBE IN SPEAKING COMPETENCE BY USING NOTE CARD, KNOWN AS CUE CARD
}

\author{
Nelia Fariani Siregar \\ Universitas Swadaya Gunung Jati (UGJ) Cirebon \\ Email: Nelia_fariani@yahoo.com
}

\section{Abstract}

Speaking actually, is very important to be mastered because it can help us to communicate with others well. Speaking is used as a communicate tool to express the idea's feeling, accept and transfer the information to other people. In another statement, it is the activity for sharing the information. Speaking enables students to receive information from people by their conversation. Based on preliminary research, the researcher found that there are some problems in speaking at Senior High School. Most of students are still afraid to speak English in front of the class because students are not confident to speak using English and they are lack of vocabulary. The students consider that English is a hard foreign language; they are fear of making mistakes, especially in Grammar. Thus, to make them have courage in speaking English, they need bugs motivation from the teacher. There are still many students asks question or answer teacher's question by using first language (mother tongue) than using English. Most of students still feel anxious, shy and fear. This situation makes students have low achievement in speaking subject. Based on the brief explanation above, there are some problems in speaking. However, there is a way to solve the problems; one of way is using cue card as media in teaching speaking. Cue card is not something now in English teaching.

Keywords: Cue Card, Speaking; Descriptive Text

\section{Pendahuluan}

Speaking actually, is very important to be mastered because it can help us to communicate with others well. Speaking is used as a communicate tool to express the idea's feeling, accept and transfer the information to other people. In another statement, it is the activity for sharing the information. Speaking enables students to receive information from people by their conversation.

English speaking skill is very important to participate in the wider world of work. Speaking is an oral production in life (Murni, 2013). According to (Thornbury, 2012) "Speaking is so much a part of daily life that we take it for being granted". When people speak, they give and share the information. However many people feel so hard to speak in English, In fact, the students face difficulties in speaking such as hardly to arrange the sentences, afraid of making mistakes and less of motivation.

Based on preliminary research, the researcher found that there are some problems in speaking at Senior High School. Most of students are still afraid to speak English in 
front of the class because students are not confident to speak using English and they are lack of vocabulary. The students consider that English is a hard foreign language, they are fear of making mistakes, especially in Grammar. Thus, to make them have courage in speaking English, they need bugs motivation from the teacher. There are still many students asks question or answer teacher's question by using first language (mother tongue) than using English. Most of students still feel anxious, shy and fear. This situation makes students have low achievement in speaking subject.

In learning the activity, speaking has various functions. One of them is describing object. Descriptive text is one of the test given to the tenth grade and it is the text than should be mastered by students. In speaking, descriptive text the students used is to tell the characteristics of something such as things or places. This text also gives the students to study how to describe something.

Based on the brief explanation above, there are some problems in speaking. However, there is a way to solve the problems; one of way is using cue card as media in teaching speaking. Cue card is not something now in English teaching

Based on the brief explanation above, there are some problems in speaking. However, there is a way to solve the problems; one of way is using cue card as media in teaching speaking. Cue card is not something now in English teaching. Harmer at (Ochieng'Ong'ondo \& Borg, 2011) states that. "Cue card is card with words of picture, which are used to encourage the students to response".

This Journal has a tittle "Improving Student's ability to describe in Speaking Competence by Using Note Card, known as Cue Card". In this journal tells about, used Note Card or it is known as the Cue Card as a media in teaching speaking skill. The result from the research, researcher is able to clarify that the using of note card is able to improve students' descriptive speaking competence (Ariati, 2016). The different from this research is the researcher used classroom action research while this research used quantitative research. The researcher used population of Senior High School (Brown \& Abeywickrama, 2010).

\section{Method}

This research the writer will take the experimental method. Experimental method consist two groups there are experimental class and control class. According to (Fraenkel, Wallen, \& Hyun, 2012), "Experimental group is the most conclusive of scientific methods". The writer uses the quantitative as the approach of the research. (Creswell, 2011) said that, quantitative research is phenomena collecting the data that collect the data or analysis the data by using mathematically as a quantification of statistic.

Based on the statement above, the writer uses the method of experimental research. The purpose is to investigate the result of uses cue card in teaching speaking.

According to (Fraenkel et al., 2012), research design is the arrangement of condition to collecting and analysis of data in doing that purpose to investigate the effect of a method. This research uses quantitative research. The writer takes quasi 
experimental design using. The research which uses two groups; experimental group and control group. The first group to experimental group which uses cue card and second group is the control group that without cue cards (Titin, 2020). To support the expiation below. In the design that is formulated by (Fraenkel et al., 2012), pasien dengan Uji korelasi spearman's rho (Corellation Spearman's rho test). kapan sebaiknya antibiotika dievaluasi agar pengobatan lebih optimal (Pamela, 2011).

\section{Result And Discussion}

The aim of this research is to find out whether the use cue card is effective or not to the students speaking of descriptive text. Cue cards are cards with words and pictures on them, which is used to encourage the students to respond in pair or group work. The researcher introduce cue card to the students. The researcher shows the cue card in front of the class and than the researcher explained how to speak descriptive using it. After all students knew that they had to do, the researcher asked come forword in pairs two to take on cue card. Cue card was not difficult to be used in teaching speaking descriptive text of people. This media active the students to explore their ideas in describing people in teaching speaking.

Based on the researcher experience in teaching speaking descriptive text using cue card. The writer found that $t_{\text {account }}$ was higher than $t_{\text {table }} 3,260 t_{\text {account }}$ and 2,002 $t_{\text {table }}$ it could be concluded that the use cue card is effective for the students speaking of descriptive text.it can be proved by the data of pre-test and post-test. Whereas, the data of post-test was higher than pre-test. Because in using this media did not really have many problem. The researcher only had to pay extra attention to the students who were shy and reluctant to speak up in describing people (Masitoh \& Suprijadi, 2015).

For the students' responses, the researcher used questionnaire to collected the data. There were ten questions in the form that the students had to answer in the questionnaire. The students' responses through questionnaire showed that the students also feel helped to speak up in English in front of the class after using cue card and feel more interest in teaching speaking after using cue card. They supported the use of cue card in teaching speaking descriptive text. The media helped the students to speak up in English and more active in speaking class. Cue card helped the students to explore their ideas in describing people. The students agreed that by using cue card and feel happy to learn English speaking. Therefore, cue card was successfully applied in teaching speaking descriptive text at tenth grade.

Based on the research finding and the data analyzed, the writer could take conclusion that use of cue card in teaching speaking descriptive text was effective because cue card make students feel easy to make descriptive text in teaching speaking descriptive text and the students feel confident to speak up in the class. And for the students' responses after all the procedure were conducted the writer finds that almost students have positive responses towards teaching speaking descriptive text using cue card at senior high school. 


\section{Conclusion}

In this section, the writer described the conclusion that has got from the problem of research in the chapter 1 . The research it self was done at the tenth grade students of SMAN 1 Beber. Based on the aim of research questions which is to find out the using cue card is effective in teaching speaking descriptive text. The result of the research shows that students who were taught by using cue card was very effective. The writer has explained before that if $t_{\text {account }}$ is higher than $t_{\text {table }}$, so the hyphotesis (Ha) is accepted. But if $t_{\text {account }}$ is lower than ttable, so the hyphotesis (Ha) is rejected. In this research, $t_{\text {account }}$ result from both result of pre-test and post-test in experimental class and control class is higher than $t_{\text {table. }}$. The result in chapter 4 the writer found that $t_{\text {table }}$ shows the result of 0,975 with $\mathrm{d} f 58$, so the value $\mathrm{t}_{\text {table }}$ is 2,002 and the result of $\mathrm{t}_{\text {account }} 3,260$. So, the use of cue card in teaching speaking is effective, because the result of $t_{\text {account }}$ is higher than $t_{\text {table }}$ ... the alternative hypothesis is accepted. The writer concluded that the using of the card in teaching speaking had benefits and its effective in teaching process. From the result of questionnaire the writer find our learning process using cue card. From the data of questionnaire, we may conclude that the students liked learn speaking using cue card, students chose yes of each statement. This descriptive text using cue card is effective and response of cue card. 


\section{BIBLIOGRAFI}

Ariati, Ruri. (2016). Improving Students's Descriptive Speaking Competence By Using Cue Cards At The Grade VIII 2 Of Public Junior High School 03 Bengkulu City. Joall (Journal of Applied Linguistics \& Literature), 1(1), 9-20.

Brown, H. Douglas, \& Abeywickrama, Priyanvada. (2010). Language assessment: Principles and classroom practices (Vol. 10). Pearson Education White Plains, NY.

Creswell, John W. (2011). Educational Research, USA: Pearson Educational, Inc.

Fraenkel, Jack R., Wallen, Norman E., \& Hyun, Helen H. (2012). How to design and evaluate research in education (Vol. 7). McGraw-Hill New York.

Masitoh, Siti, \& Suprijadi, Dasep. (2015). Improving Students'ability In Writing Descriptive Text Using Genre Based Approach (GBA) At The Eighth Grade Students Of SMP Islam Terpadu Fitrah Insani. Eltin Journal, Journal of English Language Teaching in Indonesia, 3(1).

Murni, Sri Minda. (2013). Improving Students'speaking Skill In Expressing Offering By Using Role Play Technique. Transform Journal of English Language Teaching and Learning of FBS Unimed, 2(2).

Ochieng'Ong'ondo, Charles, \& Borg, Simon. (2011). 'We teach plastic lessons to please them': The influence of supervision on the practice of English language student teachers in Kenya. Language Teaching Research, 15(4), 509-528.

Pamela, Dina Sintia. (2011). Evaluasi Kualitatif Penggunaan Antibiotika Dengan Metode Gyssens di Ruang Kelas 3 Infeksi Departemen Ilmu Kesehatan Anak RSCM Secara Prospektif. Depok: Fakultas Kedokteran, Universitas Indonesia.

Thornbury, Scott. (2012). Speaking instruction. The Cambridge Guide to Pedagogy and Practice in Second Language Teaching, 198-206.

Titin, Nurhayatin. (2020). Teaching Speaking Descriptive Text Using Cue Card At Senior High School. Voice of English Learners, 1(1). 